\title{
Endoscopic resection of an anal gland cyst
}

A 61-year-old woman presented with the chief complaint of anal bleeding. On digital examination, a 5-mm elastic soft tumor was palpated in the posterior wall of the anal canal. Colonoscopy was performed which demonstrated a transparent 5-mm submucosal tumor in the posterior wall below the dentate line ( $\bullet$ Fig. $\mathbf{1}$ a, b).

For endoscopic resection, it is difficult to visualize the interior of the anal canal, and resection below the dentate line can be painful. Therefore, a transparent tip hood was attached to a colonoscope for good visualization of the anal canal, and $1 \%$ lidocaine was injected using a 25-G needle (Top, Tokyo, Japan) for local anesthesia. Lidocaine was first injected into the submucosa at the upper end of the dentate line, without pain, under retroflexed observation in the rectum. Then the transparent tip hood was used for endoscopy of the anal canal ( $\bullet$ Fig. 2 a). A second submucosal injection of lidocaine was then administered below the dentate line. The mucosal layer was elevated and en bloc mucosal resection was performed ( Fig. 2b). Pathologic examination revealed a cystic tumor $5 \mathrm{~mm}$ in diameter covered by squamous epithelium, and glandular tissue composed of simple columnar epithelium in the lumen ( $\bullet$ Fig. 3). The final diagnosis was an anal gland cyst (AGC).

Because glandular epithelial tissue is observed in the lumen of AGCs, they are thought to be retention cysts in the anal gland which arise when obstruction of the anal duct [1] causes fluid collection in the anal gland. [1,2]. AGCs are rare and seen in only $0.05 \%$ of patients undergoing anal surgery [2,3]. AGCs are usually treated by transanal resection; there have been no reports of endoscopic resection [1-4]. This is the first report of painless endoscopic mucosal resection of an AGC in the anal canal.

Endoscopy_UCTN_Code_TTT_1AQ_2AD

Competing interests: None

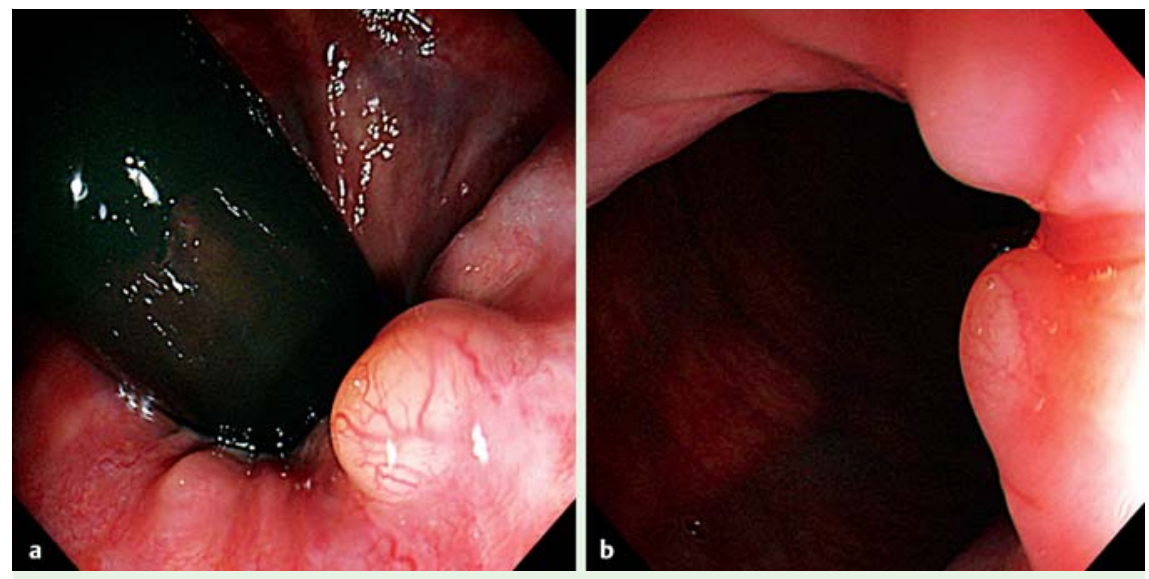

Fig. 1 a Reversed endoscopic view of a transparent, cystic 5-mm submucosal tumor in the posterior wall below the dentate line, under. $\mathbf{b}$ It is difficult to get a good view in the anal canal.
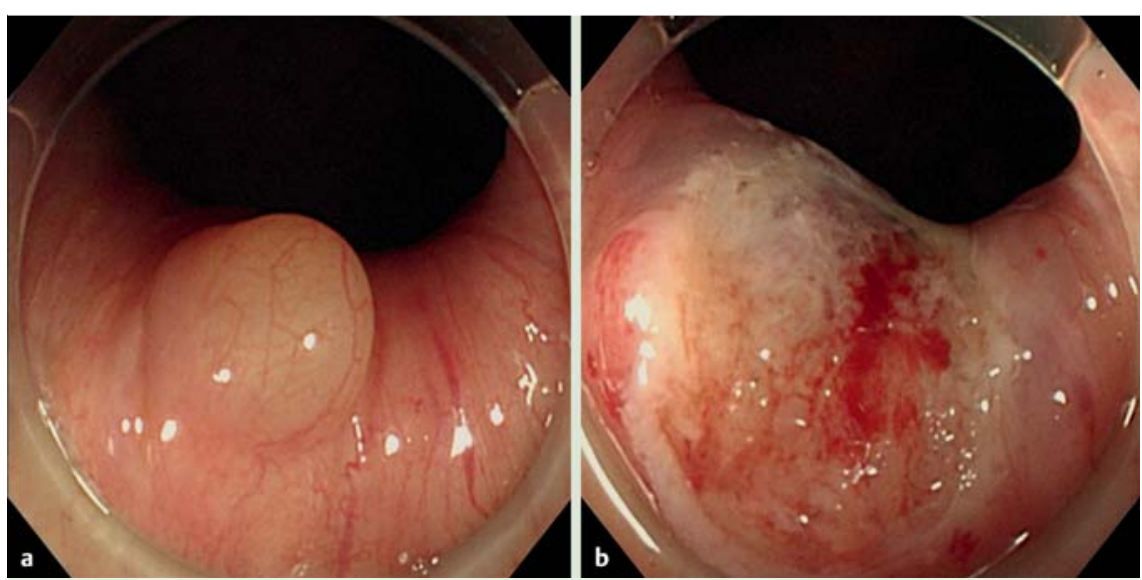

Fig. 2 a A transparent tip hood was attached to the colonoscope for good visualization in the anal canal. b Painless endoscopic mucosal resection was performed using local anesthesia with $1 \%$ lidocaine below the dentate line.
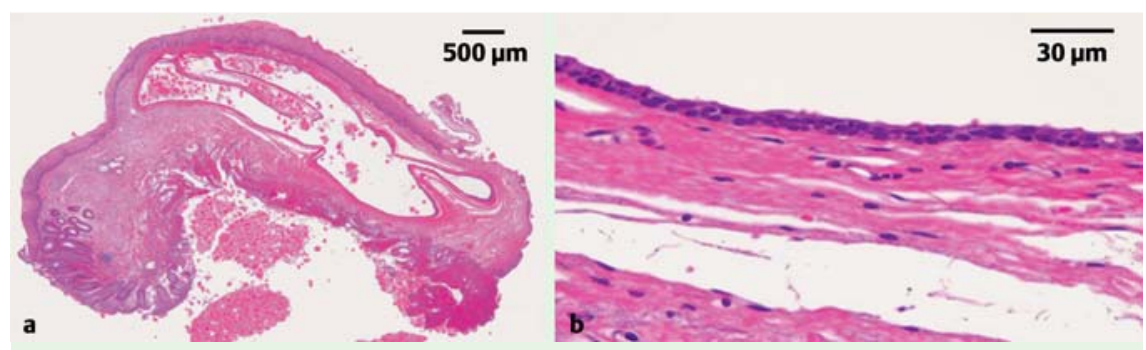

Fig. 3 a Microscopic examination revealed a cystic tumor of $5 \mathrm{~mm}$ in diameter covered by squamous epithelium. b Glandular tissue composed of simple columnar epithelium in the lumen. 


\section{K. Uchimoto ${ }^{1}$, N. Nishigori ${ }^{1}$, H. Fujii ${ }^{2}$,} F. Koyama ${ }^{1}$, T. Nakagawa ${ }^{1}$, S. Nakamura $^{1}$, T. Ueda ${ }^{1}$, Y. Nakajima ${ }^{1}$

1 Department of Surgery, Nara Medical University, Nara, Japan

2 Department of Endoscopy and Ultrasound, Nara Medical University, Nara, Japan

\section{References}

1 Kikuta S, Suda K, Nagayoshi H. Anal gland cyst.Gastrointestinal syndrome. 2nd edn. [in Japanese]. Osaka: Nippon-Rinsho; 2009: $802-804$

2 Arakawa J, Arakawa K. Perianal cyst related to anal duct. Dis Colon Rectum 1965; 8: $67-72$

3 Ozawa K, Kanai T, Kurihara H et al. Clinicopathological study of 6 patients with perianal cyst. [in Japanese with English abstract]. J Jpn Soc Coloproctol 2006; 59: 124-129

4 Kulaylat MN, Doerr RJ, Neuwirth M et al. Anal duct/gland cyst: report of a case and review of the literature. Dis Colon Rectum 1998; 41: $103-110$

\section{Bibliography}

DOI $10.1055 / \mathrm{s}-0030-1255901$

Endoscopy 2011; 43: E43-E44

(c) Georg Thieme Verlag KG Stuttgart · New York . ISSN 0013-726X

\section{Corresponding author} K. Uchimoto, MD

Department of Surgery Nara Medical University 840 Shijyocho Kashihara Nara 634-8522

Japan

Fax: +81-744-24-6866

k-uchi@naramed-u.ac.jp 